\title{
The Future of EU-Finances
}

\section{Ed. by Thiess Büttner and Michael Thöne}

[Die Zukunft des EU-Finanzwesens.]

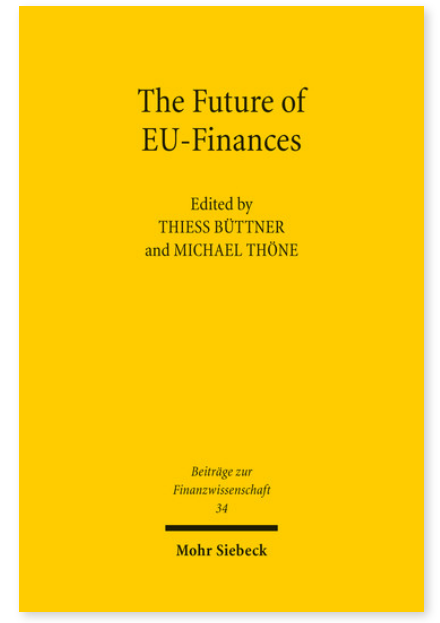

2016. VII, 165 Seiten. BtrFin 34

ISBN 978-3-16-154786-7

DOI 10.1628/978-3-16-154786-7

eBook PDF $64,00 €$

ISBN 978-3-16-154656-3

fadengeheftete Broschur $64,00 €$
Veröffentlicht auf Englisch.

Dieses Buch vereint unterschiedliche Analysen zum gegenwärtigen Finanzierungssystem der Europäischen Union und zu möglichen Reformmodellen für die Zukunft. Wichtige neue politische Herausforderungen, wie die Politik der EU gegenüber internationalen Konflikten und die Flüchtlingskrise, deuten darauf hin, dass es ein großes Potenzial für eine stärkere Rolle der EU gibt. Eine Reform des Einnahmensystems kann ein wichtiger Schritt sein, um zu gewährleisten, dass die Union in der Lage ist, diese Anforderungen zu erfüllen. Es darf jedoch nicht übersehen werden, dass auch gewichtige politische Differenzen zwischen den EU-Mitgliedstaaten herrschen. Aus dieser Perspektive könnte eine Einnahmen-Reform, die lediglich als ein weiterer Schritt in Richtung einer »immer engeren Union« dient, möglicherweise nicht dazu dienen, diese Herausforderungen besser zu bewältigen. Der Band präsentiert eine Sammlung ausgewählter Aufsätze von Experten aus Wirtschafts- und Rechtswissenschaftlern, die viele Aspekte derartiger Reformen behandeln.

Inhaltsübersicht

Thiess Büttner/Michael Thöne: The Future of EU Finances - Synopsis - Alfons Weichenrieder/Vilen Lipatov: The Subsidiarity Principle as a Guideline for Financing the European Budget - Thiess Büttner: Revenue Smoothing by the EU Funding System Christos Kotsogiannis: European Union and Own Revenue Resources - (Brief) Lessons from Fiscally Decentralized Economies - Massimo Bordignon/Simona Scabrosetti: The Political Economy of Financing the EU Budget - Friedrich Heinemann: Strategies for a European EU Budget - Michael Thöne: Transferring Taxes to the Union: The Case of European Road Transport Fuel Taxes - Kai Konrad: Light for Europe - An Electricity Tax for the European Union Budget - Christian Waldhoff: Legal Restrictions and Possibilities for Greater Revenue Autonomy of the EU

Thiess Büttner Born 1966; studied Economics in Göttingen and Konstanz; Dr.rer.pol University of Konstanz; 2004-10 Professor of Economics at the University of Munich; since 2010 Professor of Economics at the University of ErlangenNuremberg.

Michael Thöne Born 1967; studied Economics and Political Sciences in Cologne and at Trinity College Dublin; Dr.rer.pol. University of Cologne; since 2005 Managing Director of FiFo Institute for Public Economics at the University of Cologne.

Jetzt bestellen:

https://mohrsiebeck.com/buch/the-future-of-eu-finances-9783161547867?no_cache=1

order@mohrsiebeck.com

Telefon: $+49(0) 7071-923-17$

Telefax: +49 (0)7071-51104 